\title{
Mitochondria and chromaffin cell function
}

\author{
Javier García-Sancho • Antonio M. G. de Diego • \\ Antonio G. García
}

Received: 14 December 2011 / Revised: 5 January 2012 / Accepted: 9 January 2012 /Published online: 27 January 2012

(C) Springer-Verlag 2012

\begin{abstract}
Chromaffin cells are an excellent model for stimulus-secretion coupling. $\mathrm{Ca}^{2+}$ entry through plasma membrane voltage-operated $\mathrm{Ca}^{2+}$ channels (VOCC) is the trigger for secretion, but the intracellular organelles contribute subtle nuances to the $\mathrm{Ca}^{2+}$ signal. The endoplasmic reticulum amplifies the cytosolic $\mathrm{Ca}^{2+}\left(\left[\mathrm{Ca}^{2+}\right]_{\mathrm{C}}\right)$ signal by $\mathrm{Ca}^{2+}$ induced $\mathrm{Ca}^{2+}$ release (CICR) and helps generation of microdomains with high $\left[\mathrm{Ca}^{2+}\right]_{\mathrm{C}}(\mathrm{HCMD})$ at the subplasmalemmal region. These HCMD induce exocytosis of the docked secretory vesicles. Mitochondria close to VOCC take up large amounts of $\mathrm{Ca}^{2+}$ from HCMD and stop progression of the $\mathrm{Ca}^{2+}$ wave towards the cell core. On the other hand, the increase of $\left[\mathrm{Ca}^{2+}\right]$ at the mitochondrial matrix stimulates respiration and tunes energy production to the increased needs of the exocytic activity. At the end of stimulation, $\left[\mathrm{Ca}^{2+}\right]_{\mathrm{C}}$ decreases rapidly and mitochondria release the $\mathrm{Ca}^{2+}$ accumulated in the matrix through the $\mathrm{Na}^{+} / \mathrm{Ca}^{2+}$ exchanger. VOCC, CICR sites and nearby mitochondria form functional triads that co-localize at the subplasmalemmal area, where secretory vesicles wait ready for exocytosis. These triads optimize stimulus-secretion coupling while avoiding
\end{abstract}

This article is published as part of the special issue on "Cell-specific roles of mitochondrial $\mathrm{Ca}^{2+}$ handling."

J. García-Sancho $(\bowtie)$

Instituto de Biología y Genética Molecular (IBGM),

Universidad de Valladolid and CSIC,

c/Sanz y Forés, 3 ,

47003, Valladolid, Spain

e-mail: jgsancho@ibgm.uva.es

A. M. G. de Diego • A. G. García

Instituto Teófilo Hernando; Departamento de Farmacología y

Terapéutica; Servicio de Farmacología Clínica,

Instituto de Investigaciones Sanitarias del Hospital de la Princesa;

Facultad de Medicina, Universidad Autónoma de Madrid,

Madrid, Spain propagation of the $\mathrm{Ca}^{2+}$ signal to the cell core. Perturbation of their functioning in neurons may contribute to the genesis of excitotoxicity, ageing mental retardation and/or neurodegenerative disorders.

Keywords Mitochondria · Chromaffin cell · Calcium · Mitochondrial calcium uniporter - Aequorin · Calcium microdomains $\cdot$ Exocytosis
Abbreviations
ER Endoplasmic reticulum
$\left[\mathrm{Ca}^{2+}\right]_{\mathrm{C}} \quad$ Cytosolic $\mathrm{Ca}^{2+}$ concentration
$\left[\mathrm{Ca}^{2+}\right]_{\mathrm{M}}$ Mitochondrial $\mathrm{Ca}^{2+}$ concentration
$\left[{ }^{\mathrm{T}} \mathrm{Ca}\right] \quad$ Total calcium concentration
CICR Calcium-induced calcium release
HCMD High $\mathrm{Ca}^{2+}$ microdomains
VOCC Voltage-operated $\mathrm{Ca}^{2+}$ channels
MCU Mitochondrial $\mathrm{Ca}^{2+}$ uniporter
SERCA Sarcoendoplasmic reticulum $\mathrm{Ca}^{2+}$-activated ATPase
SOC Store-operated $\mathrm{Ca}^{2+}$ entry also known as capacitative $\mathrm{Ca}^{2+}$ entry

\section{Introduction}

The adrenal gland is responsible for the adjustment of many physiological functions to demanding or stressful conditions through secretion of the catecholamines adrenaline and noradrenaline. In addition, $\mathrm{Ca}^{2+}$ triggering of adrenaline secretion from chromaffin cells has been used as a general model for stimulus-secretion coupling [20]. According to the initial formulation, stimulus promotes $\mathrm{Ca}^{2+}$ entry, which increases the cytosolic $\mathrm{Ca}^{2+}$ concentration $\left(\left[\mathrm{Ca}^{2+}\right]_{\mathrm{C}}\right)$ and 
triggers exocytosis [20, 21]. Later studies showed that the genesis of the $\left[\mathrm{Ca}^{2+}\right]_{\mathrm{C}}$ signal includes subtle nuances contributed by the intracellular $\mathrm{Ca}^{2+}$-handling organelles $[5,8$, $24,25]$. To begin with, $\mathrm{Ca}^{2+}$ entering through the plasma membrane $\mathrm{Ca}^{2+}$ channels is buffered by cytosolic $\mathrm{Ca}^{2+}$ buffers, so that the increase of $\left[\mathrm{Ca}^{2+}\right]_{C}$ is much less than expected. On the other hand, organelles interrupt physically the diffusion pathways and make them much longer and tortuous. In addition, many organelles avidly take up $\mathrm{Ca}^{2+}$ and drain the $\mathrm{Ca}^{2+}$ wave; on the contrary, other organelles amplify the $\left[\mathrm{Ca}^{2+}\right]_{\mathrm{C}}$ signal by releasing $\mathrm{Ca}^{2+}[3,5,7,55]$. In this way high $\left[\mathrm{Ca}^{2+}\right]_{\mathrm{C}}$ microdomains (HCMD) are built at the secretion site whereas $\left[\mathrm{Ca}^{2+}\right]_{\mathrm{C}}$ near the resting level is preserved at the cell core. Mitochondria play a prominent role in shaping the $\left[\mathrm{Ca}^{2+}\right]_{\mathrm{C}}$ signal in chromaffin cells [24]. On the other hand, changes of $\mathrm{Ca}^{2+}$ concentration in the mitochondrial matrix $\left(\left[\mathrm{Ca}^{2+}\right]_{\mathrm{M}}\right)$ modify the rate of respiration $[27,32,47,49,51]$ and, when excessive, can trigger cell death [22].

\section{Calcium buffering differs among different subcellular compartments}

It is a general observation that calcium binds avidly to endogenous $\mathrm{Ca}^{2+}$-binding proteins in all the intracellular compartments including the cytosol, so that the total calcium concentration $\left(\left[{ }^{\mathrm{T}} \mathrm{Ca}\right]\right)$ is always much larger than the ionised one $\left(\left[\mathrm{Ca}^{2+}\right]\right)$. The ratio $\mathrm{d}\left[{ }^{\mathrm{T}} \mathrm{Ca}\right] / \mathrm{d}\left[\mathrm{Ca}^{2+}\right]$ or calcium-binding capacity [40] quantifies this buffering effect. Differences in buffering power among different compartments do not generate $\left[\mathrm{Ca}^{2+}\right]$ gradients but differences in their $\left[{ }^{\mathrm{T}} \mathrm{Ca}\right]$. On t4he other hand, the calcium content of a given organelle determines his potential weight on the generation of global $\left[\mathrm{Ca}^{2+}\right]_{\mathrm{C}}$ signals. For example, the magnitude of the $\left[\mathrm{Ca}^{2+}\right]_{\mathrm{C}}$ peak generated by $\mathrm{Ca}^{2+}$ release from a given organelle depends on the ratio of the calcium-buffering powers ( $\left.B_{\text {organelle }} / B_{\text {cytosol }}\right)$ and the volume ratio $\left(V_{\text {organelle }} / V_{\text {cytosol }}\right)$. Other parameters that should be considered when evaluating the influence of organellar $\mathrm{Ca}^{2+}$ transport on $\mathrm{Ca}^{2+}$ signalling are kinetics (faster flows generate neater $\left[\mathrm{Ca}^{2+}\right]_{\mathrm{C}}$ signals) and distance to the $\mathrm{Ca}^{2+}$ target (closer location gives stronger effect).

The calcium-binding capacity $\left(\kappa_{\mathrm{S}}\right)$ of the cytosol may differ widely among different cell types. $\kappa_{\mathrm{S}}$ values 1,000 have been reported for myocytes [58] and various neuronal types $[1,23,46,54]$. On the other hand, values of $40-100$ have been reported for rat chromaffin cells $[11,29]$ and bovine chromaffin cells $[40,60,63]$.

The approximate values of several relevant parameters in order to estimate the effects of calcium redistribution among different compartments are summarized in Table 1. The last column compares the size of the different $\mathrm{Ca}^{2+}$ pools at rest when all are expressed in the same units (in millimoles per litre of cells). It seems clear from these values that release of even a small fraction of the endoplasmic reticulum (ER) or secretory granules (SG) $\mathrm{Ca}^{2+}$ pools would produce a big $\left[\mathrm{Ca}^{2+}\right]_{\mathrm{C}}$ increase. This is accepted for ER, but opinions on the relevance of the secretory granules pool for cytosolic signalling are controversial. While the classical view stated that $\mathrm{Ca}^{2+}$ exchanges between the secretory granules pool and the cytosol are too slow to participate in $\left[\mathrm{Ca}^{2+}\right]_{\mathrm{C}}$ signalling, it has been proposed recently that secretory granules possess $\mathrm{Ca}^{2+}$ channels that can be activated by second messengers and that they could be activated under physiological conditions [44, 61]. The calcium contained in other acidic granules, such as lysosomes or endosomes (not shown in Table 1), could also play a role [43], although the size of this pool is much smaller. Finally, it has been proposed that the nucleus could also contain a releasable $\mathrm{Ca}^{2+}$ pool stored within the nuclear envelope and their invaginations to the nucleoplasm, the nucleoplasmic reticulum, as well as complexed inside nuclear nanovesicles that are below electron microscope resolution [4, 62]. The mitochondria store little or no calcium in the resting condition (Table 1), but they can take up very quickly a large amount of $\mathrm{Ca}^{2+}$ when $\left[\mathrm{Ca}^{2+}\right]_{\mathrm{C}}$ increases, and then release it slowly to the cytosol when $\left[\mathrm{Ca}^{2+}\right]_{\mathrm{C}}$ declines (see below).

Cytosolic $\mathrm{Ca}^{2+}$ buffering and diffusion in bovine chromaffin cells has been extensively studied by Neher and coworkers [40,60,63]. The cytosol has a total binding capacity of $4 \mathrm{mM}$, and the endogenous $\mathrm{Ca}^{2+}$ buffer is fast (association rate $=10^{-8} \mathrm{M}^{-1} \mathrm{~s}^{-1}$ ), poorly mobile, and with low affinity for $\mathrm{Ca}^{2+}$ (dissociation constant $=100 \mu \mathrm{M}$ ). The calcium-binding capacity $\left(\mathrm{d}\left[{ }^{\mathrm{T}} \mathrm{Ca}\right] / \mathrm{d}\left[\mathrm{Ca}^{2+}\right]_{\mathrm{C}}\right)$ of the endogenous buffer is about 40 . Cytosolic buffering slows down $\mathrm{Ca}^{2}$ ${ }^{+}$mobility to reach an apparent diffusion rate of about $10^{-7} \mathrm{~cm}^{2} \mathrm{~s}^{-1}$. The two-dimensional apparent diffusion coefficient is about $40 \mu \mathrm{m}^{2} \cdot \mathrm{s}^{-1}$ and shows inhomogeneities at
Table 1 Calcium pools in chromaffin cells

Approximate figures based on published data $[6,7,26-28,45$, 53, 59-63]

${ }^{\mathrm{a}}$ In the resting condition. The figure in parentheses is expressed as fold relative to cytosol

\begin{tabular}{lccccc}
\hline Compartment & Relative volume & {$\left[{ }^{\mathrm{T}} \mathrm{Ca}\right]$ in M } & Ca-binding capacity $\left(\kappa_{\mathrm{S}}\right) \begin{array}{l}{\left[\mathrm{Ca}^{2+}\right]} \\
\text { in M }\end{array}$ & $\begin{array}{l}\text { Mol } \cdot 1 \text { of cells }^{-1} \\
(\text { relative size })^{\mathrm{a}}\end{array}$ \\
\hline Cytosol & 0.70 & $4 \cdot 10^{-6}$ & 40 & $1 \cdot 10^{-7}$ & $2.8 \cdot 10^{-6}(1)$ \\
Mitochondria & 0.05 & $1 \cdot 10^{-4}$ & 1,000 & $1 \cdot 10^{-7}$ & $5.0 \cdot 10^{-6}(\times 2)$ \\
ER & 0.10 & $2 \cdot 10^{-2}$ & 20 & $1 \cdot 10^{-3}$ & $2.0 \cdot 10^{-3}(\times 714)$ \\
Secretory granules & 0.15 & $4 \cdot 10^{-2}$ & 800 & $5 \cdot 10^{-5}$ & $6.0 \cdot 10^{-3}(\times 2,142)$ \\
\hline
\end{tabular}


the nuclear envelope and at the plasma membrane [37]. Brief opening of voltage-operated $\mathrm{Ca}^{2+}$ channels (VOCC) generates microdomains of high $\left[\mathrm{Ca}^{2+}\right]_{\mathrm{C}}$ near the mouth of the channel which can be detected in $\mathrm{Ca}^{2+}$ imaging measurements [40]. In such microdomains $\mathrm{Ca}^{2+}$ can reach concentrations as high as $10 \mu \mathrm{M}$ and perhaps $100 \mu \mathrm{M}[10,38]$. Because of rapid diffusion of $\mathrm{Ca}^{2+}$ towards the surrounding cytosol, $\left[\mathrm{Ca}^{2+}\right]_{\mathrm{C}}$ microdomains are very much restricted in time and space $[38,39]$. The presence of mobile buffers accelerates diffusion and opposes development of HCMD [52]. For example, $50 \mu \mathrm{M}$ fura-2 in the cytosol increases the rate of diffusion fourfold [63].

\section{High $\mathrm{Ca}^{2+}$ microdomains}

$\mathrm{Ca}^{2+}$ signalling becomes all or none at the molecular level, as very high $\mathrm{Ca}^{2+}$ concentrations are required to trigger $\mathrm{Ca}^{2}$ ${ }^{+}$-dependent processes. The $\left[\mathrm{Ca}^{2+}\right]_{\mathrm{C}}$ concentration peaks measured with $\mathrm{Ca}^{2+}$ probes are usually underestimated, as they represent the global value, which is the average HCMD and other cell locations with much lower $\left[\mathrm{Ca}^{2+}\right]_{\mathrm{C}}$. The probability of generation of an HCMD increases very much with the coincidence in time and space of the opening of many calcium channels. This depends on four dimensions, the three spatial coordinates $(x, y$ and $z$ ) and time $(t)$, which can be regarded as the degrees of freedom that oppose HCMD generation. In excitable cells, the generation of HCMD is very much favoured. The $z$ coordinate for the calcium channels is severely restricted, as the channel has to lie within the plasma membrane plane. In addition, channels may tend to pack together in clusters, thus introducing additional restrictions on $x$ and $y$. Finally, because the channel openings are synchronized by the action potential, the $t$ dimension is also severely restricted. The result is that the probability for HCMD generation at the subplasmalemmal region and coincident in time with action potentials is very much increased in excitable cells.

$\mathrm{Ca}^{2+}$ release from the intracellular $\mathrm{Ca}^{2+}$ stores may also favour formation of HCMD; the spatial coordinates of the $\mathrm{Ca}^{2+}$ channels of the stores are also restricted, as they can only locate at the ER membrane. In this case a specific HCMD topography can be favoured by the geometric disposition of the ER and its spatial relation to other organelles or morphological differentiations, for example mitochondria, nucleus or secretory vesicles (SV) [18, 50]. Finally local gradients of channel agonists, such as InsP3, must also synchronize the opening of $\mathrm{Ca}^{2+}$ channels that are physically close in space. $\mathrm{Ca}^{2+}$-induced $\mathrm{Ca}^{2+}$ release (CICR), which is observed for both ryanodine receptors and InsP3 receptors [15], also tends to restrict the time span, thus increasing the probability of a HCMD.

\section{Calcium entry by activation of VOCC. Coupling to transport by the endoplasmic reticulum}

$\mathrm{Ca}^{2+}$ entry through VOCCs in chromaffin cells has been studied with great detail [29, 60, 63]. Membrane depolarisation to $0 \mathrm{mV}$ elicits $\mathrm{Ca}^{2+}$ currents peaking near $800 \mathrm{pA}$ that deactivate with a half-time of $300-500 \mathrm{~ms}$. In bovine chromaffin cells, a depolarising stimulus lasting for $0.5 \mathrm{~s}$ typically elicits a mean $I_{\mathrm{Ca}}$ of $250 \mathrm{pA}$, which, in terms of $\mathrm{Ca}^{2+}$ flow, is equivalent to $700 \mu \mathrm{mol} \cdot 1 \mathrm{cells}^{-1} \cdot \mathrm{s}^{-1}$ [63]. Measurements of ${ }^{45} \mathrm{Ca}$ uptake by bovine chromaffin cells depolarised with high $\mathrm{K}^{+}$during $5 \mathrm{~s}$ gave rates of $0.7 \cdot 10^{-15} \mu \mathrm{mol} \cdot 1 \mathrm{cells}^{-1} \cdot \mathrm{s}^{-1}$, which are equivalent to $400 \mu \mathrm{mol} \cdot 1$ cells $^{-1} \cdot \mathrm{s}^{-1}$ [9], a value reasonably consistent with the measured currents.

When we measured the rate of $\left[\mathrm{Ca}^{2+}\right]_{\mathrm{C}}$ increase in chromaffin cells depolarised with high $\mathrm{K}^{+}$, we found values of $1 \mu \mathrm{mol} \cdot 1 \mathrm{cells}^{-1} \cdot \mathrm{s}^{-1}$ [55]. This is only 1 of 700 of the estimated $\mathrm{Ca}^{2+}$ entry. Taking into account the binding to cytosolic $\mathrm{Ca}^{2+}$ buffers, we would expect a rate of $700 / 40=$ $17.5 \mu \mathrm{mol} \cdot 1 \mathrm{cells}^{-1} \cdot \mathrm{s}^{-1}$, which is still much larger than the measured value, suggesting that more than $90 \%$ of the entering $\mathrm{Ca}^{2+}$ is muffled [54] by transport out of the cytosol. Using aequorins targeted to different organelles delivered by a herpes virus [2], we were able to measure the contribution of the different transport processes [55]. Results are summarized in Fig. 1. The rate of $\mathrm{Ca}^{2+}$ entry was $700 \mu \mathrm{mol} \cdot 1 \mathrm{cells}^{-1} \cdot \mathrm{s}^{-1}$, but the $\Delta\left[\mathrm{Ca}^{2+}\right]_{\mathrm{C}}$ (taking into account cytosolic buffering) was only $40 \mu \mathrm{mol} \cdot 1$ cells $^{-1} \cdot \mathrm{s}^{-1}$. The difference was due to pumping out $\mathrm{Ca}^{2+}:$ (1) to the extracellular medium through the plasma membrane $\left(20-100 \mu \mathrm{mol} \cdot 1\right.$ cells $\left.^{-1} \cdot \mathrm{s}^{-1}\right)$; (2) inside ER $\left(70-80 \mu \mathrm{mol} \cdot 1 \mathrm{cells}^{-1} \cdot \mathrm{s}^{-1}\right)$; and (3) inside mitochondria, which is, by far, the largest component, more than $90 \%$ of the total entry (Fig. 1) [55].

$\mathrm{Ca}^{2+}$ transport by the ER is tricky because of the balance among uptake via the sarcoendoplasmic reticulum $\mathrm{Ca}^{2+}$ ATPase (SERCA) and release via CICR. Uptake by SERCA increases exponentially with $\left[\mathrm{Ca}^{2+}\right]_{\mathrm{C}}$ and can reach maximal rates $70-80 \mu \mathrm{mol} \cdot 1 \mathrm{cells}^{-1} \cdot \mathrm{s}^{-1}$, at $1-5 \mu \mathrm{M}\left[\mathrm{Ca}^{2+}\right]_{\mathrm{C}}[3,55$, $60]$. At the steady state, the ER fills to a level of 500 $1,000 \mu \mathrm{M}\left[\mathrm{Ca}^{2+}\right]$. In this condition the rate of ER-cytosol $\mathrm{Ca}^{2+}$ exchange is about $2-3 \mu \mathrm{mol} \cdot 1 \mathrm{cells}^{-1} \cdot \mathrm{s}^{-1}$. Maximal stimulation of CICR with caffeine increases this leak 10-20 times $[3,55]$ and virtually empties of $\mathrm{Ca}^{2+}$ the ER. The stimulus for CICR is the sudden increase of $\left[\mathrm{Ca}^{2+}\right]_{\mathrm{C}}$. The threshold at which uptake via SERCA is substituted by release via CICR depends on several factors, including ER filling degree. $\mathrm{Ca}^{2+}$ entry via $\mathrm{HVA} \mathrm{Ca}{ }^{2+}$ channels activated by high $\mathrm{K}^{+}$depolarization is able to induce net $\mathrm{Ca}^{2+}$ release from the ER [3], suggesting that an HCMD high enough to activate CICR is formed near the sites of $\mathrm{Ca}^{2+}$ entry. This probably coexists in time with other more remote locations of the ER where the increase of $\left[\mathrm{Ca}^{2+}\right]_{\mathrm{C}}$ is insufficient to trigger $\mathrm{Ca}^{2+}$ release. Instead, net ER $\mathrm{Ca}^{2+}$ uptake resulting 


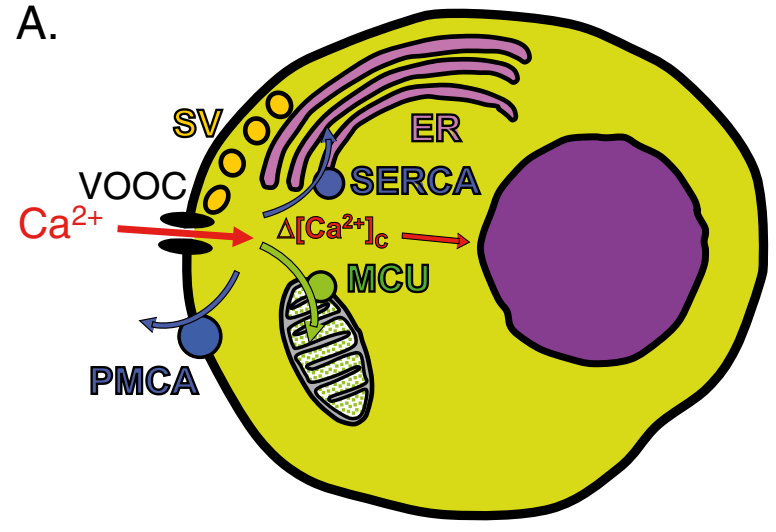

B.

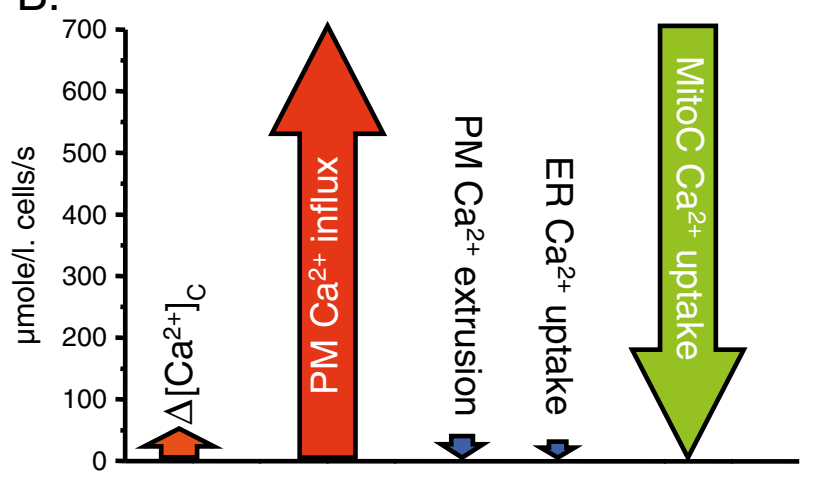

C.

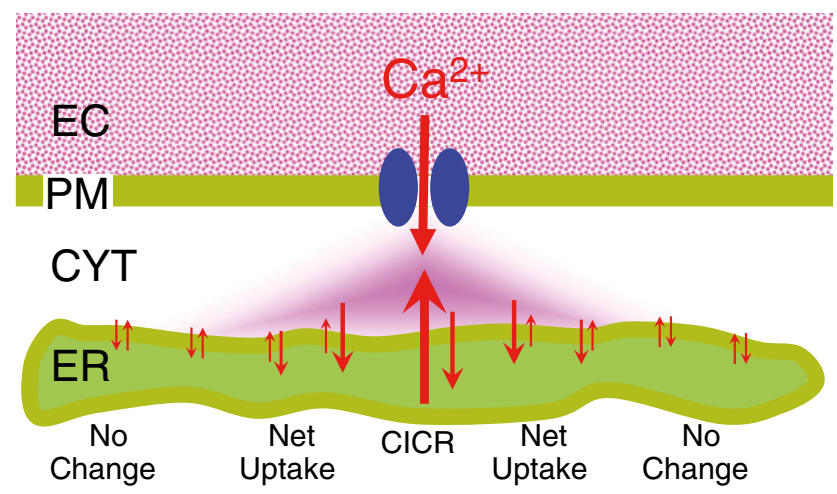

Fig. 1 Redistribution of $\mathrm{Ca}^{2+}$ entering through voltage-operated $\mathrm{Ca}^{2+}$ channels $(V O C C)$ in chromaffin cells. a $\mathrm{Ca}^{2+}$ enters through VOCC and then it can be pumped back to the extracellular medium through plasma membrane $\mathrm{Ca}^{2+}$-dependent ATPase (PMCA), taken up into the endoplasmic reticulum $(E R)$ through the sarcoendoplasmic reticulum $\mathrm{Ca}^{2+}$-dependent ATPase (SERCA) or into mitochondria via the mitochondrial calcium uniporter $(M C U)$. $S V$ secretory vesicles. b Compares transport through each transport system. $P M$ plasma membrane. $\Delta\left[\mathrm{Ca}^{2+}\right]_{\mathrm{C}}$, increase of the cytosolic $\mathrm{Ca}^{2+}$ concentration, measured with fura-2. $\mathrm{c} \mathrm{Ca}^{2+}$-induced $\mathrm{Ca}^{2+}$ release $(C I C R) . \mathrm{Ca}^{2+}$ entering from the extracellular $(E C)$ medium through VOCC of the plasma membrane $(P M)$ generates a local hotspot that activates $\mathrm{Ca}^{2+}$ release from ER via the ryanodine receptor channel (red arrow), which amplifies the original signal. In other parts of the ER, there is net $\mathrm{Ca}^{2+}$ uptake via SERCA. CYT cytosol

from the increase of $\left[\mathrm{Ca}^{2+}\right]_{\mathrm{C}}$ would be observed at these locations (Fig. 1c). That is why CICR is so difficult to evidence and also why it is so efficient, as $\mathrm{Ca}^{2+}$ is released just over the target. In addition, $\mathrm{Ca}^{2+}$ missing the target is taken up again by ER and rereleased at the right place. Coupling of CICR to function is probably due to physical relationships.

\section{Mitochondrial calcium transport}

Chromaffin cell mitochondria accumulate large amounts of $\mathrm{Ca}^{2+}$ during stimulation with either high $\mathrm{K}^{+}$solutions, acetylcholine or caffeine [36]. $\mathrm{Ca}^{2+}$ is taken up through the mitochondrial $\mathrm{Ca}^{2+}$ uniporter (MCU), a protein associated to the inner mitochondrial membrane that has been cloned recently [12, 19] (Fig. 2a). MCU is a low-affinity/highcapacity system that uses the mitochondrial membrane potential $\left(\psi_{\mathrm{m}}\right)$ as the driving force for $\mathrm{Ca}^{2+}$ uptake [27]. Since $\psi_{\mathrm{m}}$ at rest is -150 to $-180 \mathrm{mV}$, this transport system would promote accumulation of $\mathrm{Ca}^{2+}$ into the mitochondrial matrix up to five to six orders of magnitude above $\left[\mathrm{Ca}^{2+}\right]_{\mathrm{C}}$ at the thermodynamic equilibrium [13]. $\mathrm{Ca}^{2+}$ exit from mitochondria takes place through a $\mathrm{Na}^{+} / \mathrm{Ca}^{2+}$ exchanger and also through a $\mathrm{Na}^{+}$-independent system, the former being dominant in the adrenal medulla [27] (Fig. 2a). The calciumbinding capacity for $\mathrm{Ca}^{2+}\left(\kappa_{\mathrm{S}}\right)$ inside the mitochondrial matrix seems to be very high, in the $10^{3}$ range $[11,17,29$, 30]. In addition, it has been proposed recently that precipitation of $\mathrm{Ca}_{3}\left(\mathrm{PO}_{4}\right)_{2}$ into the matrix con account for additional, almost unlimited, buffering [16, 57].

It has been repeatedly reported that mitochondria can clear cytosolic $\mathrm{Ca}^{2+}$ loads in rat $[11,29,57]$ and bovine chromaffin cells $[36,55,60]$. We have studied the kinetics of uptake by mitochondria in permeabilized bovine chromaffin cells infected with mitochondria-targeted aequorin probes $[36,55]$. Measured mitochondrial uptake nicely fitted to the equation

$v=\left\{V_{\max } \cdot\left(\left[\mathrm{Ca}^{2+}\right]_{\mathrm{C}}\right)^{2}\right\} /\left\{\left(K_{50}\right)^{2}+\left(\left[\mathrm{Ca}^{2+}\right]_{\mathrm{C}}\right)^{2}\right\}$

where $V_{\max }=158 \mu \mathrm{M} \cdot \mathrm{s}^{-1}$ and $K_{50}=23 \mu \mathrm{M}$. The $K_{50}$ value is similar to both, the one obtained previously with isolated mitochondria from liver and heart and bovine adrenal medulla $(10-15 \mu \mathrm{M})[26,27]$ and the one estimated by Xu et al. [60] from measurements of the decrease of $\left[\mathrm{Ca}^{2+}\right]_{\mathrm{C}}$ in intact bovine chromaffin cells $(40 \mu \mathrm{M})$. The value of $V_{\max }$ we estimate above would be equivalent to $6,320 \mu \mathrm{mol} \cdot 1 \mathrm{cells}^{-1} \cdot \mathrm{s}^{-1}$, not far from the 4,800 value estimated by $\mathrm{Xu}$ et al. using an entirely different procedure based on clearance of $\mathrm{Ca}^{2+}$ photoreleased to the cytosol from a caged compound [60].

Because of the enormous driving force pushing $\mathrm{Ca}^{2+}$ from the cytosol towards the mitochondrial matrix, transport through the MCU is usually unidirectional. However, when the mitochondria depolarize, the electrochemical gradient 
Fig. 2 Mitochondrial $\mathrm{Ca}^{2+}$

transport in chromaffin cells. a

Scheme of the different

mechanisms. $\mathrm{Ca}^{2+}$ entry

happens via the mitochondrial

uniporter, driven by the

membrane potential $\left(\psi_{m}\right)$. Exit

happens via $\mathrm{Na}^{+} / \mathrm{Ca}^{2+}$ exchange

(left) and $\mathrm{H}^{+} / \mathrm{Ca}^{2+}$ exchange

(right). The permeability

transition pore $(P T P)$, which is

normally closed, is shown on

top. b Comparison of

appearance of $\mathrm{Ca}^{2+}$ into the

cytosol (red trace; scale at left; measured with fura-4F) and into the mitochondria (green dotted trace, scale at left, measured with low-affinity mitochondrial aequorin). $\mathrm{Ca}^{2+}$ entry was triggered by depolarization with high $\mathrm{K}^{+}(70 \mathrm{mM} ; 10 \mathrm{~s})$. c The $\mathrm{Na}^{+} / \mathrm{H}^{+}$exchange inhibitor CGP37157 (20 $\mu \mathrm{M}$; blue trace) blocks exit of $\mathrm{Ca}^{2+}$ from mitochondria in chromaffin cells

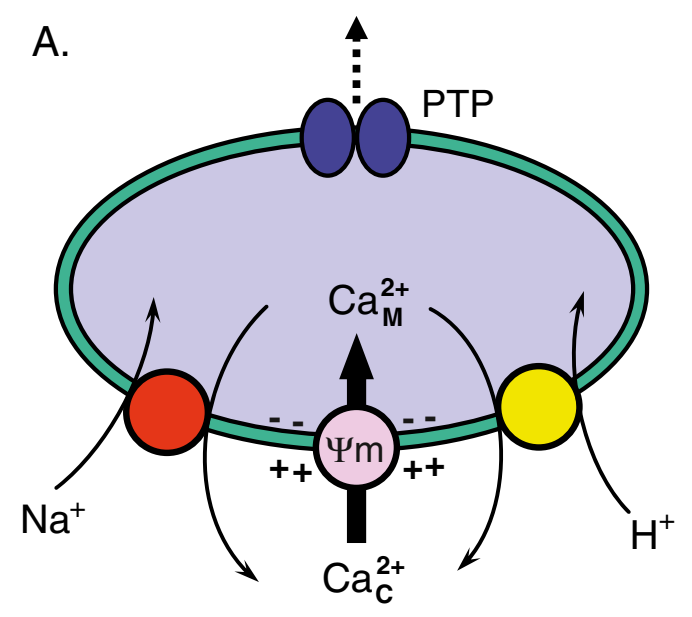

B.

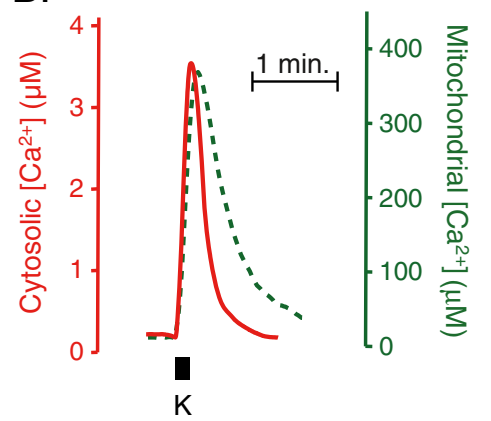

C.

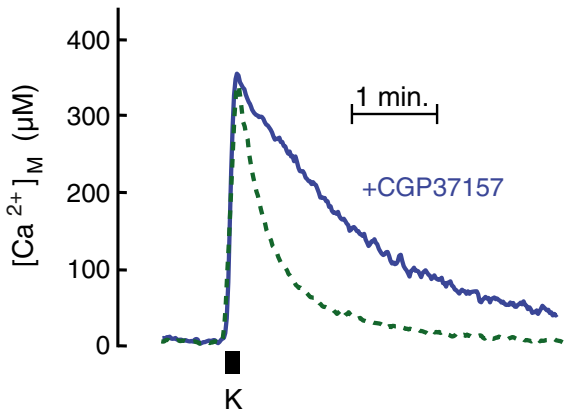

for $\mathrm{Ca}^{2+}$ collapses and the uniporter may mediate $\mathrm{Ca}^{2+}$ exit from the matrix of $\mathrm{Ca}^{2+}$-loaded mitochondria. Under these circumstances, the increase of $\left[\mathrm{Ca}^{2+}\right]_{\mathrm{C}}$ may trigger the process and induce massive $\mathrm{Ca}^{2+}$ release, the so-called mitochondrial CICR (mCICR) [35]. Opening of the permeability transition pore (Fig. 2a) can also produce mCICR [31].

Under normal conditions, the exit of $\mathrm{Ca}^{2+}$ from $\mathrm{Ca}^{2+}$ loaded mitochondria takes place mainly through the $\mathrm{Na}^{+} / \mathrm{Ca}^{2}$ ${ }^{+}$exchanger (Fig. 2a) [26]. In our study with bovine chromaffin cells [55], mitochondrial release (at $37^{\circ} \mathrm{C}$ ) had a sigmoidal kinetics that could be fitted by the following equation:

$v=\left\{V_{\max } \cdot\left(\left[\mathrm{Ca}^{2+}\right]_{\mathrm{M}}\right)^{2}\right\} /\left\{K_{50}+\left(\left[\mathrm{Ca}^{2+}\right]_{\mathrm{M}}\right)^{2}\right\}$

with $K_{50}=217 \mu \mathrm{M}$ and $V_{\max }=20 \mu \mathrm{M} / \mathrm{s}$, which would be equivalent to $780 \mu \mathrm{mol} \cdot 1 \mathrm{cells}^{-1} \cdot \mathrm{s}^{-1}$, one order of magnitude smaller than $V_{\max }$ for mitochondrial $\mathrm{Ca}^{2+}$ uptake (see above). Sigmoidicity disappeared at $22^{\circ} \mathrm{C}$. The $\mathrm{Na}^{+} / \mathrm{Ca}^{2+}$ exchanger inhibitor CGP37157 antagonized mitochondrial $\mathrm{Ca}^{2+}$ exit, both at $37^{\circ} \mathrm{C}$ and at $22^{\circ} \mathrm{C}$ [55].

\section{Mitochondrial $\mathrm{Ca}^{2+}$ uptake during activation of adrenal chromaffin cells}

Activation of chromaffin cells is started by activation of plasma membrane VOCC and $\mathrm{Ca}^{2+}$ entry. The resulting
$\left[\mathrm{Ca}^{2+}\right]_{\mathrm{C}}$ peak is followed by a mitochondrial $\left[\mathrm{Ca}^{2+}\right]_{\mathrm{M}}$ increase (Fig. 2b). When stimulus ceases $\left[\mathrm{Ca}^{2+}\right]_{\mathrm{C}}$ relaxes and so does, with some delay, $\left[\mathrm{Ca}^{2+}\right]_{\mathrm{M}}$. Inhibitors of the $\mathrm{Na}^{+} / \mathrm{Ca}^{2+}$ exchanger slows down mitochondrial $\mathrm{Ca}^{2+}$ clearance (Fig. 2c). The $\left[\mathrm{Ca}^{2+}\right]_{\mathrm{M}}$ peaks are then longer than the $\left[\mathrm{Ca}^{2+}\right]_{\mathrm{C}}$ counterparts. Since several NADH dehydrogenases are stimulated by $\mathrm{Ca}^{2+}$ in the micromolars range [27], the increase of $\left[\mathrm{Ca}^{2+}\right]_{\mathrm{M}}$ stimulates respiration and ATP synthesis [55] and this contributes to provide the energy needed to restore the perturbations generated during activation. The fact that the $\left[\mathrm{Ca}^{2+}\right]_{\mathrm{M}}$ peak is longer than the $\left[\mathrm{Ca}^{2+}\right]_{\mathrm{C}}$ one is a kind of "respiration debt" that secures restoration of the initial state. $\left[\mathrm{Ca}^{2+}\right]_{\mathrm{M}}$ can remain above micromolars levels for several minutes after cell stimulation [57].

The amount of calcium taken up into mitochondrial could be very large. During maximal stimulation of $\mathrm{Ca}^{2+}$ entry trough VOCC $\left[\mathrm{Ca}^{2+}\right]_{\mathrm{M}}$ peaks as high as $300-400 \mu \mathrm{M}$ can be reached $[36,55]$ (Fig. 2b, c). Should all this $\mathrm{Ca}^{2+}$ be bound, this would make a $\left[{ }^{\mathrm{T}} \mathrm{Ca}\right]$ of $300-400 \mathrm{mM}$. A part of this calcium could precipitate as calcium phosphate into the mitochondrial matrix thus not generating osmotic stress $[16,57]$. The value of the solubility product is compatible with the figures obtained here.

Note that the $\mathrm{Ca}^{2+}$ overload that enters through the plasma membrane during chromaffin cell stimulation is taken up preferentially by mitochondria, with very little uptake into ER (Fig. 1). This is to be expected from the characteristics 
of $\mathrm{Ca}^{2+}$ transport by the different organelles in chromaffin cells. Figure 3 compares fluxes through VOCC (dotted line) with uptake by SERCA and mitochondria at different $\left[\mathrm{Ca}^{2+}\right]_{\mathrm{C}}$. At rest $\left[\mathrm{Ca}^{2+}\right]_{\mathrm{C}}$ of about $10^{-7} \mathrm{M}(\mathrm{R}$ in Fig. 3), there is no measurable uptake by mitochondria whereas SERCA works at $10-20 \%$ of $V_{\max }$. Consequently $\mathrm{Ca}^{2+}$ accumulates into the ER at about $0.5-1 \cdot 10^{-3} \mathrm{M}$. During maximal activation of VOOC, HDCA of $10^{-5}$ to $10^{-4} \mathrm{M}\left[\mathrm{Ca}^{2+}\right]_{\mathrm{C}}$ are formed near the plasma membrane $\mathrm{Ca}^{2+}$ channels $[10,38,55]$. Under these conditions (A2 in Fig. 3 ), $\mathrm{Ca}^{2+}$ is taken up mainly by mitochondria. Note that: (1) even though ER is accumulating $\mathrm{Ca}^{2+}$ at its $V_{\max }$, the uptake by mitochondria is about 100-fold faster because of the high capacity of the mitochondrial uniporter; and (2) $V_{\max }$ of the uniporter is still ten times as large as the influx through VOCC and hence enough to muffle the $\mathrm{Ca}^{2+}$ overload (Fig. 3). We have demonstrated recently that, contrarily to what happens in chromaffin cells, the $\mathrm{Ca}^{2+}$ overload induced by activation of store-operated calcium entry (SOC; a plasma membrane channel that activates when the intracellular calcium stores are emptied) is taken up mainly into the ER in several cell models $[6,33,34]$. We attribute this difference to the fact that HCMD seen by mitochondria during activation of the SOC are smaller, in the $10^{-6}$ range (A1 in Fig. 3). This is enough to promote near maximal uptake into the ER, but uptake through the uniporter is relatively small (10-100 times slower).

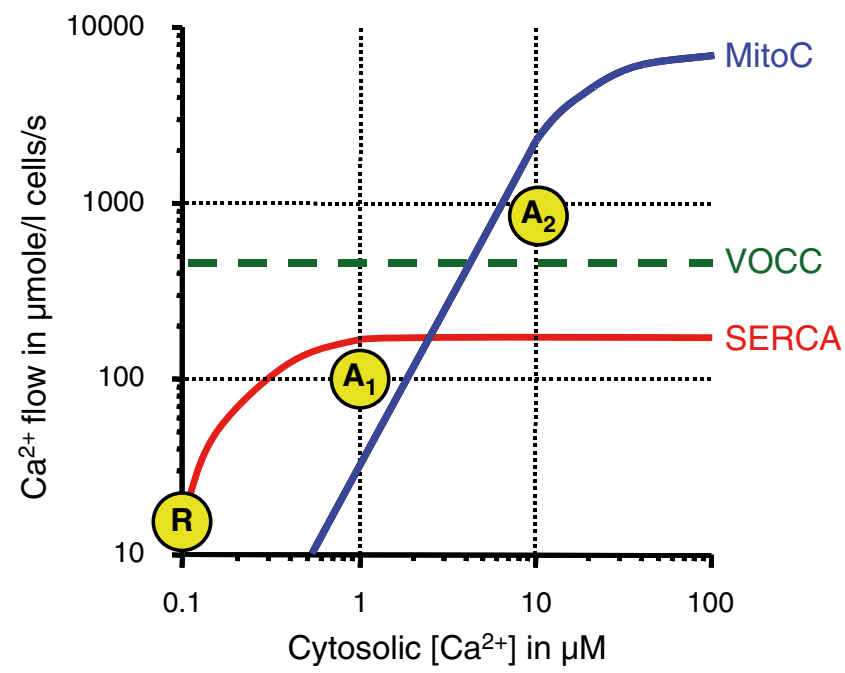

Fig. 3 Comparison of the concentration-dependence of several $\mathrm{Ca}^{2+}$ transport sytems. Entry through VOCC is fixed at $700 \mu$ mole 1 cells $^{-1}$. $\mathrm{s}^{-1}$ (green dotted trace). Pumping through SERCA (red trace) and the uniporter (blue trace, labelled MitoC) were calculated using the equation: $v=\left\{V_{\max } \cdot\left(\left[\mathrm{Ca}^{2+}\right]_{\mathrm{C}}\right)^{2}\right\} /\left\{\left(K_{50}\right)^{2}+\left(\left[\mathrm{Ca}^{2+}\right]_{\mathrm{C}}\right)^{2}\right\}$, with the following values for SERCA and the mitochondrial uniporter, respectively: $V_{\max }$, 200 and $7,000 \mu \mathrm{mol} \cdot 1 \mathrm{cells}^{-1} \cdot \mathrm{s}^{-1}$, and $K_{50}, 0.25$ and $15 \mu \mathrm{M}$. Note double logarithmic scale. The yellow circles represent $\left[\mathrm{Ca}^{2+}\right]_{\mathrm{C}}$ levels attained at rest $(R)$ and during activation, either close to VOCCs $\left(A_{2}\right)$ or far away from them $\left(A_{1}\right)$. Reproduced with permission from Villalobos et al. [55]
Two different mitochondrial $\mathrm{Ca}^{2+}$ pools are generated during activation of chromaffin cells

Measurements with aequorins allow to trace a memory of the $\mathrm{Ca}^{2+}$ changes, as the photoprotein is burned out in the compartments where $\left[\mathrm{Ca}^{2+}\right]$ has been high. Our results suggest the existence of two different mitochondrial pools, $\mathrm{M} 1$ and $\mathrm{M} 2$, which take up $\mathrm{Ca}^{2+}$ at very different rates in response to activation of VOOCs. Pool M1 takes up $\mathrm{Ca}^{2+}$ at a rate of about $50 \mu \mathrm{M} / \mathrm{s}, 30 \%$ of uniporter's $V_{\max }$, whereas uptake by pool M2 is about 150 times slower [36, 55]. According to the saturation kinetics parameters measured in chromaffin cells mitochondria, this corresponds to the rates obtained at about 20 and $2 \mu \mathrm{M}\left[\mathrm{Ca}^{2+}\right]_{\mathrm{C}}$, respectively. We believe that $\mathrm{M} 1$ corresponds to mitochondria close to the plasma membrane, which sense HCMD formed close to the mouth of VOCC and takes up very large amounts of calcium, thus muffling the progression of the $\mathrm{Ca}^{2+}$ wave towards the cell core (Fig. 4a). Since the sphere volume increases more than surface on moving away from the centre, the pool M1, containing $50 \%$ of mitochondria, would occupy a deepness of less than $2 \mu \mathrm{m}$ below the plasma membrane in a $15-\mu \mathrm{m}$ diameter cell (corresponding to the dotted subplasmalemmal area in Fig. 4a). This mitochondrial pool would accumulate most of the entering $\mathrm{Ca}^{2+}$ load whereas pool M2, at the cell core, would sense much smaller $\left[\mathrm{Ca}^{2+}\right]_{\mathrm{C}}$ and take up a minor fraction of the load. Electron microscopy X-ray microanalysis of frog sympathetic neurons after stimulation with high $\mathrm{K}^{+}$also revealed the existence of two mitochondrial pools with different $\mathrm{Ca}^{2+}$ contents [46] and so did aequorin in mouse sympathetic neurons [41] and pancreatic beta cells [48]. In pancreatic acinar cells, entry of $\mathrm{Ca}^{2}$ ${ }^{+}$through plasma membrane also caused preferential $\mathrm{Ca}^{2+}$ uptake into subplasmalemmal mitochondria [42].

\section{Functional triads composed by VOCC, CICR and subplasmalemmal mitochondria generate HCMD that optimize coupling to secretion}

As pointed out above, the $\left[\mathrm{Ca}^{2+}\right]_{\mathrm{C}}$ signals generated by activation of VOCC can be amplified by CICR in chromaffin cells [3]. Strategic location of VOCC, CICR sites and the mitochondrial M1 pool conforming functional triads is essential for maximizing HCMD and optimizing secretion [24, 36] (Fig. 4b). Thus $\left[\mathrm{Ca}^{2+}\right]_{\mathrm{C}}$ hotspots reach concentrations of as high as $50 \mu \mathrm{M}$ at the subplasmalemmal region, where SV are docked. VOCC is the trigger, CICR the amplifier and then subplasmalemmal mitochondria (M1) act as a contention wall that accumulates calcium and avoids propagation of the calcium wave towards the cell core. The increase of $\left[\mathrm{Ca}^{2+}\right]_{\mathrm{M}}$ stimulates respiration $[26,27,32,47]$, thus tuning local energy production to the increased needs of the 


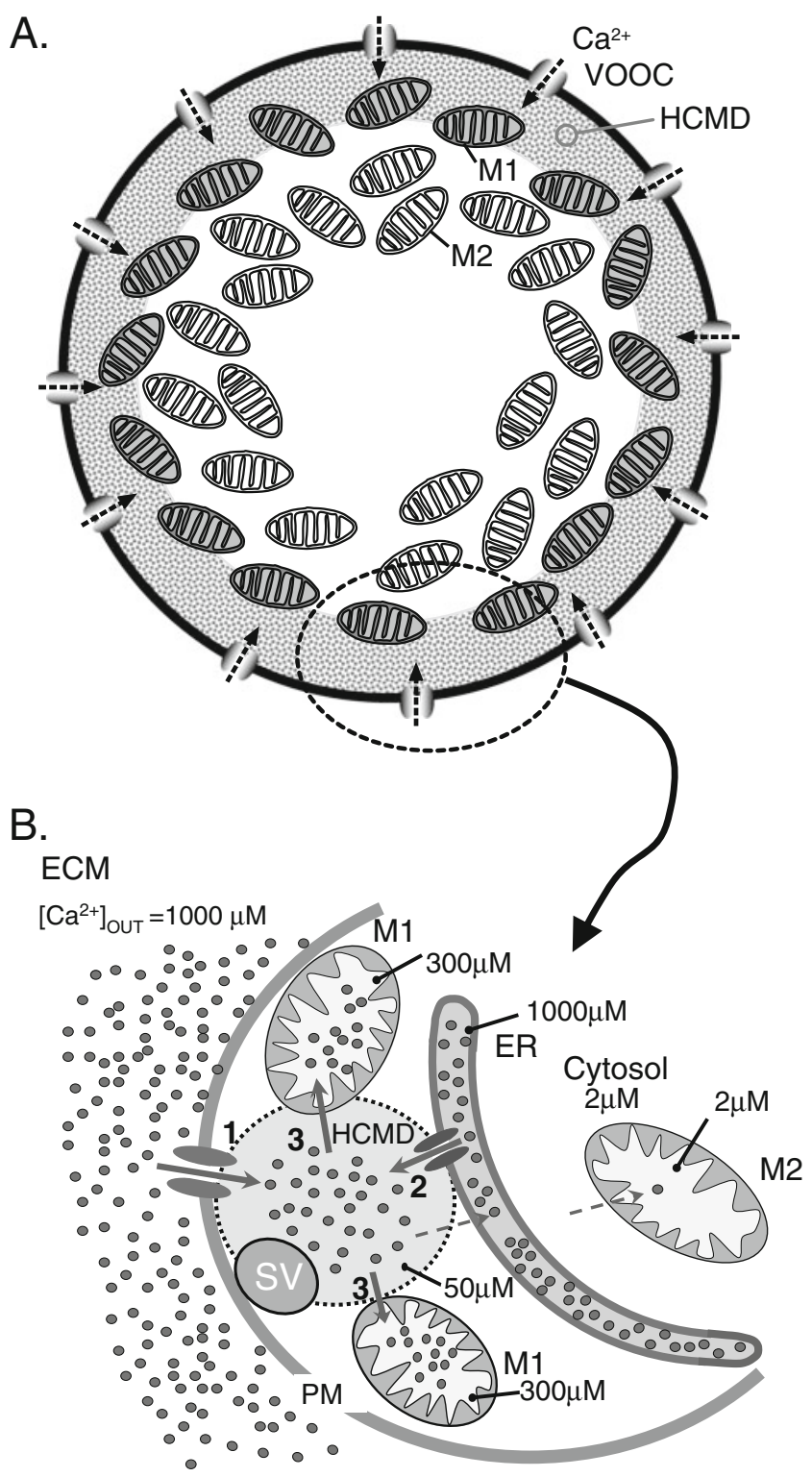

Fig. 4 Spatial disposition of mitochondria in chromaffin cells. a $\mathrm{Ca}^{2+}$ enters through activated VOCC (arrows) and generates a high $\mathrm{Ca}^{2+}$ microdomain in the subplasmalemmal region (dotted area). Mitochondria close to plasma membrane $(M 1)$ take up large amounts of $\mathrm{Ca}^{2+}$ and stop progression of the $\left[\mathrm{Ca}^{2+}\right]_{\mathrm{C}}$ wave towards the cell core. Deeper mitochondria (M2) take up much less calcium, as $\left[\mathrm{Ca}^{2+}\right]_{\mathrm{C}}$ in their vicinity is well below $K_{50}$ of the mitochondrial $\mathrm{Ca}^{2+}$ uniporter. Aequorin is burned much faster in M1 than in M2 mitochondria. b Detail showing functional triads that modulate local high $\left[\mathrm{Ca}^{2+}\right]_{\mathrm{C}}$ microdomains. $\mathrm{Ca}^{2+}$ enters through VOCC (1) and generates a high $\left[\mathrm{Ca}^{2+}\right]_{\mathrm{C}}$ domain, which is amplified by $\mathrm{Ca}^{2+}$ release from the ER (2). The surrounding mitochondria $(M 1)$ avoid lateral progress of the $\mathrm{Ca}^{2+}$ wave by taking up $\mathrm{Ca}^{2+}(3)$. Note that ER does also avoid progression of the wave towards the cell core. Deeper mitochondria see much smaller concentrations of $\mathrm{Ca}^{2+}$ and do not accumulate it in their matrix (M2). The approximate $\mathrm{Ca}^{2+}$ concentrations in the extracellular medium $(E C M)$, high $\mathrm{Ca}^{2+}$ microdomain $(H C M D)$, mitochondrial matrix of pools M1 and M2 and ER lumen and bulk cytosol are shown in the figure. $P M$ plasma membrane. Note that docked secretory vesicles $(S V)$ are easily reached by the HCMD exocytic activity. Respiratory stimulation will lag behind cessation of activity until the mitochondrial calcium load is completely cleared, and this may take several minutes [57]. Much of the $\mathrm{Ca}^{2+}$ that enters mitochondria at subplasmalemmal locations may diffuse through the mitochondrial matrix to other cell locations and, eventually, be extruded from mitochondria near the cell core. This mitochondrial $\mathrm{Ca}^{2+}$ release probably contributes to keep $\left[\mathrm{Ca}^{2+}\right]_{\mathrm{C}}$ discretely raised during the poststimulus period, perhaps facilitating the transport of new vesicles to refill the readily releasable pool [56].

If the location or the $\mathrm{Ca}^{2+}$ handling properties of mitochondria in these functional triads could be regulated, this could be an effective mechanism for modulation of the exocytotic process. If these mechanisms could be extrapolated to neurons, these changes of these functional triads could contribute to modulation of synaptic plasticity. Finally, under brain stress conditions, such as excitotoxicity or ischemia-reperfusion damage, ageing or development of neurodegenerative diseases, mitochondrial dysfunction may reduce the ability of the mitochondria to muffle cytosolic $\mathrm{Ca}^{2+}$, this leading to increased secretion of excitatory neurotransmitters and cell overactivation, a vicious circle that may trigger processes leading to cell death [14]. Changes in CICR could also modulate the synaptic efficacy under physiological or pathophysiological conditions.

\section{Concluding remarks}

Since Douglas and Rubin [21] showed, in1961, that $\mathrm{Ca}^{2+}$ entry was the only requirement to trigger the acetylcholinemediated release of catecholamines from the adrenal gland, we have learned much about basic and molecular aspects of $\mathrm{Ca}^{2+}$ signalling and exocytosis in chromaffin cells. The physiologically relevant intracellular $\mathrm{Ca}^{2+}$ signals occur either as localized hot spots of high $\mathrm{Ca}^{2+}$ concentration or as propagating $\mathrm{Ca}^{2+}$ waves, which give rise to global $\mathrm{Ca}^{2+}$ elevations. The cytoplasmic organelles are essential for shaping the $\left[\mathrm{Ca}^{2+}\right]_{\mathrm{C}}$ signals in order to optimize stimulus secretion coupling. Our results suggest a highly structured spatiotemporal organization of the $\mathrm{Ca}^{2+}$ signals originated by sustained $\mathrm{Ca}^{2+}$ entry through VOCC. High $\left[\mathrm{Ca}^{2+}\right]_{\mathrm{C}}$ microdomains suitable for triggering exocytosis are generated only at the subplasmalemmal region. Domains with a much smaller $\left[\mathrm{Ca}^{2+}\right]_{\mathrm{C}}$ increase but more sustained in time, perhaps adequate for mobilizing the reserve pool of secretory vesicles, are generated at the core regions of the cytosol and at the nucleus. Mitochondria are essential for shaping adequately these local $\mathrm{Ca}^{2+}$ domains. And, on the other hand, $\mathrm{Ca}^{2+}$ uptake by mitochondria activates NADH dehydrogenases, thus tuning up respiration to match the increased local energy needs. Full relaxation of the $\left[\mathrm{Ca}^{2+}\right]_{\mathrm{C}}$ 
peak requires clearance of the mitochondrial $\mathrm{Ca}^{2+}$ load through the $\mathrm{Na}^{+} / \mathrm{Ca}^{2+}$ exchanger, which proceeds slowly at low micromolar $\left[\mathrm{Ca}^{2+}\right]_{\mathrm{M}}$ levels. This keeps respiration stimulated and core $\left[\mathrm{Ca}^{2+}\right]_{\mathrm{C}}$ discretely high for a long period after stimulation, acting as a kind of memory that may help to secure restoration of the initial conditions. Mitochondrial dysfunction impairs calcium homeostasis and stimulus-secretion coupling, and may contribute to generation of excitotoxic or neurodegenerative disorders.

Acknowledgements Financial support from the following institutions is gratefully acknowledged: To JGS, grants from the EU-ERANet program and the Spanish Ministerio de Ciencia e Innovación (MICINN), SAF2008-03175-E and BFU2010-17379, Red de Terapia Celular, Instituto de Salud Carlos III (RD06/0010/0000) and the Junta de Castilla y León (gr175). To AGG, SAF2010-21795 (MCINN); RETICS RD06/0009, Instituto de Salud Carlos III; (3) S-SAL-02752006, Comunidad Autónoma de Madrid; NDG07/9 y NDG09/8, Agencia Laín Entralgo, Comunidad Autónoma de Madrid, Spain; Fundación Teófilo Hernando.

\section{References}

1. Albrecht MA, Colegrove SL, Friel DD (2002) Differential regulation of $\mathrm{ER} \mathrm{Ca}^{2+}$ uptake and release rates accounts for multiple modes of $\mathrm{Ca}^{2+}$-induced $\mathrm{Ca}^{2+}$ release. J Gen Physiol 119:211-233

2. Alonso MT, Barrero MJ, Carnicero E, Montero M, Garcia-Sancho J, Alvarez J (1998) Functional measurements of $\left[\mathrm{Ca}^{2+}\right]$ in the endoplasmic reticulum using a herpes virus to deliver targeted aequorin. Cell Calcium 24:87-96

3. Alonso MT, Barrero MJ, Michelena P, Carnicero E, Cuchillo I, Garcia AG, Garcia-Sancho J, Montero M, Alvarez J (1999) $\mathrm{Ca}^{2+}$ induced $\mathrm{Ca}^{2+}$ release in chromaffin cells seen from inside the ER with targeted aequorin. J Cell Biol 144:241-254

4. Alonso MT, Garcia-Sancho J (2011) Nuclear Ca(2+) signalling. Cell Calcium 49:280-289

5. Alonso MT, Manjarres IM, Garcia-Sancho J (2009) Modulation of calcium signalling by intracellular organelles seen with targeted aequorins. Acta Physiol (Oxf) 195:37-49

6. Alonso MT, Manjarres IM, Garcia-Sancho J (2012) Privileged coupling between $\mathrm{Ca}(2+)$ entry through plasma membrane storeoperated $\mathrm{Ca}(2+)$ channels and the endoplasmic reticulum $\mathrm{Ca}(2+)$ pump. Mol Cell Endocrinol (in press)

7. Alonso MT, Villalobos C, Chamero P, Alvarez J, Garcia-Sancho J (2006) Calcium microdomains in mitochondria and nucleus. Cell Calcium 40:513-525

8. Alvarez J, Montero M, Garcia-Sancho J (1999) Subcellular Ca(2+) dynamics. News Physiol Sci 14:161-168

9. Artalejo CR, Garcia AG, Aunis D (1987) Chromaffin cell calcium channel kinetics measured isotopically through fast calcium, strontium, and barium fluxes. J Biol Chem 262:915-926

10. Augustine GJ, Neher E (1992) Calcium requirements for secretion in bovine chromaffin cells. J Physiol 450:247-271

11. Babcock DF, Herrington J, Goodwin PC, Park YB, Hille B (1997) Mitochondrial participation in the intracellular $\mathrm{Ca}^{2+}$ network. $\mathrm{J}$ Cell Biol 136:833-844

12. Baughman JM, Perocchi F, Girgis HS, Plovanich M, BelcherTimme CA, Sancak Y, Bao XR, Strittmatter L, Goldberger O, Bogorad RL, Koteliansky V, Mootha VK (2011) Integrative genomics identifies MCU as an essential component of the mitochondrial calcium uniporter. Nature 476:341-345
13. Bernardi P (1999) Mitochondrial transport of cations: channels, exchangers, and permeability transition. Physiol Rev 79:11271155

14. Berridge MJ (2011) Calcium signalling and Alzheimer's disease. Neurochem Res 36:1149-1156

15. Berridge MJ, Lipp P, Bootman MD (2000) The versatility and universality of calcium signalling. Nat Rev Mol Cell Biol 1:11-21

16. Chalmers S, Nicholls DG (2003) The relationship between free and total calcium concentrations in the matrix of liver and brain mitochondria. J Biol Chem 278:19062-19070

17. Coll KE, Joseph SK, Corkey BE, Williamson JR (1982) Determination of the matrix free $\mathrm{Ca}^{2+}$ concentration and kinetics of $\mathrm{Ca}^{2+}$ efflux in liver and heart mitochondria. J Biol Chem 257:86968704

18. Csordas G, Hajnoczky G (2003) Plasticity of mitochondrial calcium signaling. J Biol Chem 278:42273-42282

19. De Stefani D, Raffaello A, Teardo E, Szabo I, Rizzuto R (2011) A forty-kilodalton protein of the inner membrane is the mitochondrial calcium uniporter. Nature 476:336-340

20. Douglas WW (1968) Stimulus-secretion coupling: the concept and clues from chromaffin and other cells. Br J Pharmacol 34:451-474

21. Douglas WW, Rubin RP (1961) The role of calcium in the secretory response of the adrenal medulla to acetylcholine. J Physiol 159:40-57

22. Duchen MR, Szabadkai G (2010) Roles of mitochondria in human disease. Essays Biochem 47:115-137

23. Friel DD, Tsien RW (1994) An FCCP-sensitive $\mathrm{Ca}^{2+}$ store in bullfrog sympathetic neurons and its participation in stimulusevoked changes in $\left[\mathrm{Ca}^{2+}\right]$ i. J Neurosci 14:4007-4024

24. Garcia AG, Garcia-De-Diego AM, Gandia L, Borges R, GarciaSancho J (2006) Calcium signaling and exocytosis in adrenal chromaffin cells. Physiol Rev 86:1093-1131

25. Garcia-Sancho J, Verkhratsky A (2008) Cytoplasmic organelles determine complexity and specificity of calcium signalling in adrenal chromaffin cells. Acta Physiol (Oxf) 192:263-271

26. Gunter TE, Gunter KK, Sheu SS, Gavin CE (1994) Mitochondrial calcium transport: physiological and pathological relevance. Am J Physiol 267:C313-C339

27. Gunter TE, Pfeiffer DR (1990) Mechanisms by which mitochondria transport calcium. Am J Physiol 258:C755-C786

28. Haigh JR, Parris R, Phillips JH (1989) Free concentrations of sodium, potassium and calcium in chromaffin granules. Biochem J 259:485-491

29. Herrington J, Park YB, Babcock DF, Hille B (1996) Dominant role of mitochondria in clearance of large $\mathrm{Ca}^{2+}$ loads from rat adrenal chromaffin cells. Neuron 16:219-228

30. Horikawa Y, Goel A, Somlyo AP, Somlyo AV (1998) Mitochondrial calcium in relaxed and tetanized myocardium. Biophys $\mathrm{J}$ 74:1579-1590

31. Ichas F, Jouaville LS, Mazat JP (1997) Mitochondria are excitable organelles capable of generating and conveying electrical and calcium signals. Cell 89:1145-1153

32. Maechler P, Wollheim CB (1998) Role of mitochondria in metabolism-secretion coupling of insulin release in the pancreatic beta-cell. Biofactors 8:255-262

33. Manjarres IM, Alonso MT, Garcia-Sancho J (2011) Calcium entrycalcium refilling (CECR) coupling between store-operated $\mathrm{Ca}(2+)$ entry and sarco/endoplasmic reticulum $\mathrm{Ca}(2+)$-ATPase. Cell Calcium 49:153-161

34. Manjarres IM, Rodriguez-Garcia A, Alonso MT, Garcia-Sancho J (2010) The sarco/endoplasmic reticulum $\mathrm{Ca}(2+)$ ATPase (SERCA) is the third element in capacitative calcium entry. Cell Calcium 47:412-418

35. Montero M, Alonso MT, Albillos A, Garcia-Sancho J, Alvarez J (2001) Mitochondrial $\mathrm{Ca}(2+)$-induced $\mathrm{Ca}(2+)$ release mediated by the $\mathrm{Ca}(2+)$ uniporter. Mol Biol Cell 12:63-71 
36. Montero M, Alonso MT, Carnicero E, Cuchillo-Ibanez I, Albillos A, Garcia AG, Garcia-Sancho J, Alvarez J (2000) Chromaffin-cell stimulation triggers fast millimolar mitochondrial $\mathrm{Ca}^{2+}$ transients that modulate secretion. Nat Cell Biol 2:57-61

37. Naraghi M, Müller TH, Neher E (1998) Two-dimensional determination of the cellular $\mathrm{Ca}^{2+}$ binding in bovine chromaffin cells. Biophys J 75:1635-1647

38. Neher E (1998) Vesicle pools and $\mathrm{Ca}^{2+}$ microdomains: new tools for understanding their roles in neurotransmitter release. Neuron 20:389-399

39. Neher E (1998) Usefulness and limitations of linear approximations to the understanding of $\mathrm{Ca}++$ signals [published erratum appears in Cell Calcium 1999 Mar;25(3):275]. Cell Calcium 24:345-357

40. Neher E, Augustine GJ (1992) Calcium gradients and buffers in bovine chromaffin cells. J Physiol 450:273-301

41. Nunez L, Senovilla L, Sanz-Blasco S, Chamero P, Alonso MT, Villalobos C, Garcia-Sancho J (2007) Bioluminescence imaging of mitochondrial $\mathrm{Ca}^{2+}$ dynamics in soma and neurites of individual adult mouse sympathetic neurons. J Physiol 580:385-395

42. Park MK, Ashby MC, Erdemli G, Petersen OH, Tepikin AV (2001) Perinuclear, perigranular and sub-plasmalemmal mitochondria have distinct functions in the regulation of cellular calcium transport. EMBO J 20:1863-1874

43. Patel S, Muallem S (2011) Acidic Ca(2+) stores come to the fore. Cell Calcium 50:109-112

44. Petersen $\mathrm{OH}$, Tepikin AV (2008) Polarized calcium signaling in exocrine gland cells. Annu Rev Physiol 70:273-299

45. Phillips JH, Allison YP, Morris SJ (1977) The distribution of calcium, magnesium, copper and iron in the bovine adrenal medulla. Neuroscience 2:147-152

46. Pivovarova NB, Hongpaisan J, Andrews SB, Friel DD (1999) Depolarization-induced mitochondrial $\mathrm{Ca}$ accumulation in sympathetic neurons: spatial and temporal characteristics. J Neurosci 19:6372-6384

47. Pralong WF, Hunyady L, Varnai P, Wollheim CB, Spat A (1992) Pyridine nucleotide redox state parallels production of aldosterone in potassium-stimulated adrenal glomerulosa cells. Proc Natl Acad Sci U S A 89:132-136

48. Quesada I, Villalobos C, Nunez L, Chamero P, Alonso MT, Nadal A, Garcia-Sancho J (2008) Glucose induces synchronous mitochondrial calcium oscillations in intact pancreatic islets. Cell Calcium 43:39-47

49. Rizzuto R, Bernardi P, Pozzan T (2000) Mitochondria as all-round players of the calcium game. J Physiol 529(Pt 1):37-47
50. Rizzuto R, Pinton P, Carrington W, Fay FS, Fogarty KE, Lifshitz LM, Tuft RA, Pozzan T (1998) Close contacts with the endoplasmic reticulum as determinants of mitochondrial $\mathrm{Ca}^{2+}$ responses. Science 280:1763-1766

51. Rutter GA, Theler JM, Murgia M, Wollheim CB, Pozzan T, Rizzuto R (1993) Stimulated $\mathrm{Ca}^{2+}$ influx raises mitochondrial free $\mathrm{Ca}^{2+}$ to supramicromolar levels in a pancreatic beta-cell line. Possible role in glucose and agonist-induced insulin secretion. J Biol Chem 268:22385-22390

52. Sala F, Hernandez-Cruz A (1990) Calcium diffusion modeling in a spherical neuron. Relevance of buffering properties. Biophys J 57:313-324

53. Santodomingo J, Vay L, Camacho M, Hernandez-Sanmiguel E, Fonteriz RI, Lobaton CD, Montero M, Moreno A, Alvarez J (2008) Calcium dynamics in bovine adrenal medulla chromaffin cell secretory granules. Eur J Neurosci 28:1265-1274

54. Schwiening CJ, Thomas RC (1996) Relationship between intracellular calcium and its muffling measured by calcium iontophoresis in snail neurones. J Physiol 491(Pt 3):621-633

55. Villalobos C, Nunez L, Montero M, Garcia AG, Alonso MT, Chamero P, Alvarez J, Garcia-Sancho J (2002) Redistribution of $\mathrm{Ca}^{2+}$ among cytosol and organella during stimulation of bovine chromaffin cells. FASEB J 16:343-353

56. von Ruden L, Neher E (1993) A Ca-dependent early step in the release of catecholamines from adrenal chromaffin cells. Science 262:1061-1065

57. Warashina A (2006) Mode of mitochondrial $\mathrm{Ca}^{2+}$ clearance and its influence on secretory responses in stimulated chromaffin cells. Cell Calcium 39:35-46

58. Wendt-Gallitelli MF, Isenberg G (1991) Total and free myoplasmic calcium during a contraction cycle: $\mathrm{X}$-ray microanalysis in guineapig ventricular myocytes. J Physiol 435:349-372

59. Winkler H, Westhead E (1980) The molecular organization of adrenal chromaffin granules. Neuroscience 5:1803-1823

60. Xu T, Naraghi M, Kang H, Neher E (1997) Kinetic studies of $\mathrm{Ca}^{2+}$ binding and $\mathrm{Ca}^{2+}$ clearance in the cytosol of adrenal chromaffin cells. Biophys J 73:532-545

61. Yoo SH (2010) Secretory granules in inositol 1,4,5-trisphosphatedependent $\mathrm{Ca}^{2+}$ signaling in the cytoplasm of neuroendocrine cells. FASEB J 24:653-664

62. Yoo SH, Chu SY, Kim KD, Huh YH (2007) Presence of secretogranin II and high-capacity, low-affinity $\mathrm{Ca}^{2+}$ storage role in nucleoplasmic $\mathrm{Ca}^{2+}$ store vesicles. Biochemistry 46:14663-14671

63. Zhou Z, Neher E (1993) Mobile and immobile calcium buffers in bovine adrenal chromaffin cells. J Physiol 469:245-273 